\title{
On the SCJ report "Challenges for the national standardisation of geographical names in Japan"
}

\author{
Kohei Watanabe $^{a_{*}}$, Kohei Okamoto ${ }^{\mathrm{b}}$, Akihiko Takagi ${ }^{\mathrm{c}}$, Takashi Morita ${ }^{\mathrm{d}}$, Shigeko Haruyama ${ }^{\mathrm{e}}$, \\ Yoshiyasu Ida $^{\mathrm{f}}$, Yumiko Takizawa ${ }^{\mathrm{g}}$, Hiroshi Tanabe ${ }^{\mathrm{h}}$, Takashi Todokoro ${ }^{\mathrm{i}}$, Yoshiki Wakabayashi ${ }^{\mathrm{j}}$ \\ ${ }^{a}$ Teikyo University,kw10004@cantab.net, ${ }^{b}$ Nagoya University, ${ }^{c}$ Kyushu University, ${ }^{d}$ Hosei University, ${ }^{e}$ Mie University, \\ ${ }^{f}$ Tsukuba University, ${ }^{g}$ Cartographic Information Centre, ${ }^{h}$ Tokyo University, ${ }^{i}$ Takasaki University of Economics, ${ }^{j}$ Tokyo \\ Metropolitan University \\ * Corresponding author
}

\begin{abstract}
This paper introduces the contents of the report "Challenges for the national standardisation of geographical names in Japan", prepared by the Toponymy Subcommittee under IGU Working Group of the Planetary Science Committee, Science Council of Japan. The report suggests the establishment of a national geographical names board in Japan. It first indicates the growing awareness in the world on the importance of geographical names, including the activities of UNGEGN. This is followed by a description of current issues Japan is facing on geographical names, such as discrepancies of names used in the media and those used in textbooks, naming disputes at local authority mergers, and commercialisation of geographical names. It also described currently how the various government administration bodies deal with these issues, and points out some problems, mainly due to lack of overarching principles and coordination between agencies. Some examples of systems of other countries with a national geographical names board is shown, and finally some concrete recommendations, including an establishment of an inter-ministrial body that deals comprehensively with geographical names issues, awareness raising of society on the functions and importance of geographical names, development of human resources, and active participation in the international forum on geographical names.
\end{abstract}

Keywords: Toponymy, Standardisation, Names Board, UNGEGN

\section{Introduction}

\subsection{Preface}

The Toponymy Subcommittee under IGU Working Group of the Planetary Science Committee, Science Council of Japan (日本学術会議地球惑星科学委員会 IGU 分科会地名小委員会), in conjunction with the above IGU Working Group and the Regional Information Working Group under the Regional Studies Committee (地域研究委員会地域情報分科会), has prepared a report document on the standardisation of geographical names, titled "Challenges for the national standardisation of geographical names in Japan" (地名標準化の現状と 課題). This is a result of intensive discussion spanning five years, since November 2014. As of March 2019, the subcommittee has met 21 times since its founding in 2016.

Other than discussion among the subcommittee members (i.e., the authors of this paper), we have invited experts from Japanese government agencies, cartographic publishers, and also members of national names board of other countries in our meetings. As the initial aim was to produce a recommendation document to the government of Japan under the name of the Science Council of Japan (SCJ), many versions of the draft output have been circulated among the president and other executive members of SCJ. Numerous comments and suggestions have been received in the process and the document has gone through several revisions. In the end, the subcommittee decided to publish the document as a "report" instead of a "recommendation". This paper introduces to the international readers, the content of the abovementioned report, which is solely written in Japanese.

\subsection{Background}

Geographical names are closely linked to everybody's daily life. They appear in travel, cargo logistics, postal system, tourism, marketing, education, etc. They are essential information for government administration in carrying out important functions such as emergency services, disaster response, or tax collection. They play an important role also in legislative and judicial functions of the government.

Geographical names are part of the cultural heritage, linking together time and space. In the advanced information society, they are also an important component for building up geographical information systems.

The management of local geographical names are to be conducted by the local government, but citizens outside its jurisdiction are also legitimate stakeholders. Commercial entities such as railway companies, and also religious bodies with landmark temples and shrines are 
important actors. An institution that provides guidelines, advices, and arbitration is desired. A lack of such institution will have negative implications, as can be seen in the current basic education system, where geographical names are not standardised across different subjects

Currently there are two national laws that deal with geographical names; Local Autonomy Act, and Domicile Addressing Act. However only a fraction of all geographical names is subject to these laws, and no process of stakeholder and/or experts' involvement is stipulated in them. There is a need for a basic law that sets the principle for all geographical names.

In the international forum, United Nations Group of Experts on Geographical Names (UNGEGN), organised under the Statistical Division of the Economic and Social Council, has been holding UN Conferences on the Standardisation of Geographical names since its establishment in 1967. Several resolutions on national standardisation of geographical names have been passed in these meetings. Standardisation of geographical names is understood as integrated management of geographical names by a public institution under established principles (UNGEGN 2002). A resolution recommending the establishment of national names board was agreed at the first conference, and since then there have been several resolutions following up this recommendation (UNGEGN 2006). Many countries are making progress with the standardisation of geographical names under the each country's national names board which was established following these resolutions, or existed even before the establishment of UNGEGN.

In Japan, as a response to the resolutions, there is a meeting between the Geospatial Information Authority and the Hydrographical Authority (Marine Information department of the Coastal Guard) started to hold meetings to harmonise names on maps and charts they publish, but their activities are limited, and their aim is not fully the standardisation of geographical names.

Many academics in the world, including geographers, cartographers, and linguists have been active members of UNGEGN, however it was only in 2012 that Japanese academics joined the group for the first time.

The International Geographic Union (IGU) and the International Cartographic Association have formed a joint commission /working group on Toponymy in 2011 . They have been organising numerous academic events on the topic (UNGEGN 2014). The Science Council of Japan is member to IGU and ICA, but its involvement and participation had been low until very recently.

Within the Science Council of Japan, the IGU working group under the Planetary Science Committee is the corresponding body to IGU and ICA. The discussion on geographical names at IGU was introduced at the IGU working group in its 8 th meeting of the 22nd term (2014). A toponymy subcommittee was formed under the group and had its first meeting in 2016. Since then the establishment of a national names board is being discussed. The subcommittee organised lectures and public symposiums, inviting a wide range of people including academics, government officials, textbook publishers etc.

\section{Current Issues on geographical names in Japan}

In general, names of geographical features start as common nouns describing the feature used by the local people. The names become to be used by a wider set of people and they gradually develop into proper nouns (Kadmon 1997). Geographical names describe the relationships between the people and the environment. They can also reflect historical contexts or experiences of disasters.

Geographical names can become a source of disputes. When two communities meet, and there is a geographical feature that is named differently in the two communities, each may insist on using the names developed in their own community. Administrative actions such as the implementation of the Domicile Addressing Act or mergers of local administration have caused numerous clashes (Tanigawa 1979, Imao 2009, Kusuhara 2003). There have also been oppositions to proposals based on commercial interests to alter historical names.

Currently there is no institution that carries out an integrated administration of geographical names in Japan. As for domestic names, the local authority in which the feature is located is basically in charge. They feed information on geographical names to the Geospatial Information Agency which will put them on to fundamental maps. Place names are in principle a part of heritage of the people that shares the language, but they are often treated as if they are a property of a particular local authority.

As for foreign names, the endonymic form, exonyms well established within the Japanese language, and internationally customary uses (often English exonyms) are being used mixed in a chaotic way. For example, for Chinese names the use of kana that tries to mimic standard Chinese pronunciation, and the use of kanji with Japanese reading are causing confusions.

Basically all the ministries of the government of Japan deal with geographical names separately. In many aspects, the lack of coordination is apparent. For example, even within the education sector, the name for an identical feature is rendered differently between geography and history textbooks.

The lack of standardisation is also a stumbling block to accurate geocoding (matching of geographical names and coordinates) which is a critical component in the information age (Usui et al 2009).

\section{Administrative institutions in Japan and geographical names}

The report examines current issues relating to geographical names in Japan, such as naming decisions on the occasion of local authority mergers, revision of the address system, expression of geographical names in school education, commercialisation of naming rights, 
and products' geographical indications and appellations of origin.

From an international point of view, it is pointed out that the Romanisation system for Japanese is not standardised - there exist two main systems (kunrei and Hepburn) and their variants. For some country names, some historically established exonyms remain official (e.g. Oranda for Netherlands), while the change from one established exonym to a less established one (e.g. Gruziya to Georgia) would be considered as a makeshift response, due to lack of responsible agencies and established principles.

Current legislative provisions relating to geographical names were surveyed. Other than the Domicile Addressing Act of 1962, there is no national law regarding geographical names. On the other hand, 16 different departments in the central government were identified as those dealing with place names. The involvements of four main ministries (Land Infrastructure and Transport, Education and Science, Internal Affairs and Communication, Foreign Affairs) that have close implication with geographical names are described. All of these ministries and their attached departments play important roles in geographical names administration, but there are no guiding principles and a lack of coordination between agencies.

The Ministry of Land Infrastructure and Transport, which the Geospatial Information Authority (GSI) falls under has the function of registering names reported from local authorities. However it does not have the power to give instruction or advice local authorities on geographical naming.

Regarding the Ministry of Education and Science, despite past efforts to standardise the expression of geographical names (Mombusho 1959, Kyokasho Kenkyu Senta 1978, Kyokasho Kenkyu Senta 1994), there is the issue of discrepancy of names used in the media and textbooks. There is also a lack of correspondence of names among textbooks of different subjects (Ueno 2009) (e.g. between geography and history). There is no harmonisation between names that are selected and contained in the national gazetteer compiled by the GSI, and geographical names that are designated to be taught at schools. Within geography, there is a principle of reflecting the local appellation, but there is no responsible body in making decisions on remaining issues such as ways of choosing different ways of reading geographical names in Chinese characters, or when the local language differs from the national language (e.g. names in Catalonia). In the global forum, the value of geographical names as part of cultural heritage and the importance of promoting indigenous and minority geographical names are recognised, but there is no department that deals with these aspects.

The Ministry of Internal Affairs and Communication is in charge of local governance. There is an explicit procedure for the naming of local authorities, but that is based on the viewpoint of "how local authorities call themselves", and the notion is lacking that unlike personal names, geographical names are not an exclusive possession of local residents. It is important to recognise that all geographical names, including those outside their linguistic community, are part of the linguistic heritage; all those who use the language are stakeholders. There is no system or forum to reconcile the concerns and interests of the wider public.

The Ministry of Foreign Affairs (MoFA) plays a role in the standardisation of geographical names, as the names of Japanese embassies around the world happen to serve as an official source for country names in Japanese. However there is a lack of principle regarding the handling of exonyms and endonyms or on the reading of Chinese names, as mentioned earlier. The MoFA naming is not always used in other governmental departments or outside the government. The lack of standardisation may cause disbenefits in cases of international disputes.

Products' geographical indications and appellations of origin fall under the domain of Ministry Economic Trade and Industry as well as the Ministry of Agriculture, Forestry and Fishery. Geographical names are often used for branding location specific products. The French system for the appellations of origin of agricultural products is well known worldwide. JETRO (2009) reported that as of 2007, as many as 30 Japanese geographical names had been used and registered in China as trademarks. The national geographical names board can play a role in avoiding such things from happening. The standardisation of geographical names may also lead to economic benefits.

\section{International efforts on the standardisation of geographical names}

Regarding international aspects, the activities of UNGEGN / UNCSGN, IHO, and IGU-ICA joint commission on toponymy, are described. In general, it is pointed out that the involvement of Japanese academics is weak and that it should be encouraged and promoted. For example, there had not been any Japanese members in the executive bureau, heads of divisions, or working group convenors of UNGEGN until 2017. Except for those at the 2012 IGU regional conference in Kyoto, participation of Japanese academics had been low in sessions organised by the ICA/IGU joint commission /working group on toponymy.

The arrangements and functions of national names board of other countries (US, Germany, China, Korea, and Indonesia) are described for reference. We put a slight emphasis on Asian countries to show that although it may appear that European countries dominate the discussions at international forums, many countries in Asia have a well-developed and functional system for national standardisation of geographical names.

The US Board of Geographical Names is established in 1947 while its roots can be traced back to 1890 . It has the power to resolve all unsolved issues on geographical names, and makes decisions that are binding to all federal agencies.

In the German-speaking area, there is the Ständige Ausschuss für geographische Namen (StAGN), which deals with all geographical names in the German 
language. Germany, Austria, Switzerland, Italy, and Belgium, participate in this committee. StAGN serves as the national geographical names board for Germany, while other participating countries have their national names board on their own.

China has a committee on geographical names at the central government as well as those at the provincial level The central committee has produced a gazetteer with names in Chinese characters and corresponding Romanised transcription (Tanabe 2016, National Bureau of Surveying and Mapping 1997).

The national geographical names board in Korea is established under the Ministry of Land and Transport, based on the law on spatial information (revised Mar. 2013). There are committees at the local level as well. Geographical names other than those designated in the local autonomy law is subject to the national geographical names board.

Indonesia has a well-established national geographical names board, probably due to the need of dealing with names of a very large number of islands. The board which is established under a presidential decree comprises of three teams, each dealing with policies, implementation, and advice respectively (Lauder 2015).

\section{Towards a solution on geographical names issues}

The report concludes that there is a need of an integrated management of geographical names, and to promote their standardisation. Standardisation involves the establishment of principles and norms by a public institution. More concretely, it points out the below:

1) Need of an inter-ministrial organisation (i.e., a geographical names board), consisting of experts and researchers, to deal with issues relating to standardisation of geographical names in Japan.

2) Promotion of the notion that geographical names are part of linguistic heritage, and that they are a common property of all people that share the Japanese culture. Geographical names may be administered by local authorities, but there should be opportunities to accept advice and support of experts. At times there may be a need for arbitration between different opinions from the wider public.

3) Development of human resources to deal with the challenges on the issues of geographical names. Support and promotion of research on this field is needed. Toponymy can be a topic of various academic disciplines, including geography, cartography, linguistics, history etc.

4) Active involvement at international forums on geographical names, such as UNGEGN and IGU-ICA, should be encouraged and supported. Especially for UNGEGN, the participation of experts as well as governmental officials is important.

5) As for a concrete output, the production of a gazetteer of Japanese geographical names is important

\section{Acknowledgements}

The authors would like to acknowledge the institutional support of the Science Council of Japan. We are grateful to numerous comments and suggestions from SCJ members who were involved in reviewing the report "Challenges for the national standardisation of geographical names in Japan".

The authors received funding from Japan Society for the Promotion of Science, Grant-in-Aid for Exploratory Research 17K18257 (leader K. Okamoto).

\section{References}

Imao, Keisuke (2009) "Heisei no daigappei" ni okeru shinjichitai no meimei keikou (Tendencies of the naming of new local authorities formed in the Heisei mergers) Gengo (Language) 35(8): 20-29 Taishukan

JETRO (2009) Chugoku shohyoken bounin shutsugan taisaku manyuaru 2009 nen kaitei zouho ban (Manual to deal with misappropriated trademark registration applications in China, 2009 revised and complemented edition)

Kadmon, Naftali (1997) Toponymy: the lore, laws, and language of geographical names

Kusuhara, Yusuke (2003) Konna shimei ha mou iranai (We don't want city names like this) Tokyo-do shuppan

Kyokasho Kenkyu Senta (Textbook research centre) (1978): Chimei Hyoki no Tebiki (guidelines for expression of place names) Gyosei.

Kyokasho Kenkyu Senta (Textbook research centre) (1994): Shin Chimei Hyoki no Tebiki (new guidelines for expression of place names) Gyosei.

Lauder Allan F and Lauder Multamia R. M. T. (2015) Ubiquitous place names - Standardisation and study in Indonesia, Wacana 16(2): 383-410

Mombusho (Ministry of Education) (1959) Chimei no yobikata to kakikata - shakaika tebikisho (how to call and write place names - guidance for social studies), Osaka Kyouiku Tosho

National Bureau of Surveying and Mapping, China (1997) Gazetteer of China, The Cartographic Publishing House

Tanabe Hiroshi (2015) Kanji bunkaken ni okeru chimei hyojyunka (Standardisation of geographical names in the Synosphere) Chizu (Maps) 53(4): 2-9. Nihon Chizu Gakkai (Japan Society of Cartography)

Tanigawa, Kenichi (1979) Gendai "Chimei" Koh (Thoughts on contemporary geographical names) NHK books

United Nations Group of Experts on Geographical Names (2002) Glossary of Terms for the Standardization of Geographical Names. https://unstats.un.org/unsd /geoinfo/UNGEGN/docs/pdf/Glossary_of_terms_revise d.pdf

United Nations Group of Experts on Geographical Names (2006) Manual for the national standardization of geographical names. https://unstats.un.org/unsd /publication/seriesm/seriesm_88e.pdf 
United Nations Group of Experts on Geographical Names (2014) Report on the toponymical activities of the ICA 2012-2014. 28th UNGEGN Working Paper No.34/35 https://unstats.un.org/unsd/geoinfo/UNGEGN/docs/28th -gegn-docs/WP/WP34_The\%20joint\%20ICA.pdf

Ueno Tomoko (2009) Seikatsu no kotoba to shiteno chimei (Geographical names as vocabulary of daily speech) Gengo (Language) 35(8): 30-37 Daishukan

Usui Teruko, Hada Kosuke, Ishiyama Kazuyoshi (2009) Chimei no hyojunka to chimei jisho (Standardisation of place names and gazetteers) Chiri joho shisutemu gakkai kouen ronbunshu (Proceedings of the Geographical Information Systems Association of Japan $18: 37-40$ 